Eastern Illinois University

The Keep

Faculty Research \& Creative Activity

Biological Sciences

January 1996

\title{
Haploid plant regeneration from anther cultures of three north american cultivars of strawberry (Fragaria x ananassa Duch.)
}

Henry R. Owen

Eastern Illinois University, hrowen@eiu.edu

A. Raymond Miller

Ohio State University

Follow this and additional works at: http://thekeep.eiu.edu/bio_fac

Part of the Biology Commons

\section{Recommended Citation}

Owen, Henry R. and Miller, A. Raymond, "Haploid plant regeneration from anther cultures of three north american cultivars of strawberry (Fragaria x ananassa Duch.)" (1996). Faculty Research \& Creative Activity. 142.

http://thekeep.eiu.edu/bio_fac/142

This Article is brought to you for free and open access by the Biological Sciences at The Keep. It has been accepted for inclusion in Faculty Research \& Creative Activity by an authorized administrator of The Keep. For more information, please contact tabruns@eiu.edu. 


\title{
Haploid plant regeneration from anther cultures of three north american cultivars of strawberry (Fragaria x ananassa Duch.)
}

\author{
Henry R. Owen and A. Raymond Miller
}

Summary. A study was conducted to maxmuze plant regeneration frequencies from cultured anthers of' Chandler', 'Honeoye', and 'Redchief strawberries (Fragaria x ananassa Duch.). A comparison of auxins (IAA, NAA), cytokinins (BA, BPA, KIN) and carbohydrates (sucrose, glucose, maltose) in MS medium showed that the highest shoot regeneration across cultivars $(8 \%)$ occurred when using a medium containing 2 mgtl IAA, I mgtl BA, and $0.2 \mathrm{M}$ glucose. A comparison ofMS, NN, and HI inorganic medium (a new formulation based on the anther culture literature) solidified with either agar or gellan gum and containing IAA, BA, and glucose, showed the highest shoot regeneration across cultivars (19\%) when using HI and gellan gum. Lastly, media containing FeEDTAyielded more shoots than media containing Fe-Metalosate, and anthers cultured on Fe-EDT A media in darkness for $30 \mathrm{~d}$ followed by $30 \mathrm{~d}$ in white light produced more shoots (16\% average regeneration) than those cultured on Fe-EDTA media under white or yellow light ( $16 \mathrm{~h}$ photoperiod) for the initial $30 \mathrm{~d}(0.3 \%$ and $5 \%$ respectively). Plants were acclimated ex vitro where they flowered and set :fruit. Chromosome counts of root tip cells confirmed that haploid plants were obtained from all three cultivars.

Abbreviations: IAA: indoleacetic acid, NAA: naphthaleneacetic acid, BA: 6benzylarninopurine; BP A: N-benzyl-9-(2-tetrahydropyranyl)-adenine, KIN: 6furfurylaminopurine; MS: Murashige \& Skoog (I 962); NN: Nitsch \& Nitsch (1969)

\section{Introduction}

Cultivated strawberry (Fragaria $\mathrm{x}$ ananassa Duch.) is a highly heterozygous, octoploid species $(2 \mathrm{n}=8 \mathrm{x}=56)$. Traditional breeding efforts to improve strawberry quality and yield are labor intensive, costly, and time-consuming, since many generations of crossing and selection are routinely required for cultivar development. Reducing the ploidy level of breeding material via androgenesis may accelerate plant improvement efforts by more direct exposure of genetic traits at the haploid level, by phenotypic expression of gametes for assessment of pollen-donor potentials, and, together with chromosome redoubling techniques, by the production of highly homozygous lines for fwther use as parental lines.

Several laboratories have attempted to regenerate haploid plants via anther culture of a number of Fragaria x ananassa cultivars (Fowler eta/. 1971; Hennerty eta/. 1987; Laneri \& Damiano 1981: Quarta eta/. 1991; Rosati eta/. 1975; Sayegh \& Hennerty 1989;

Svensson \& Johansson 1994). In these investigations, however, haploid plants were not obtained. Successful regeneration of haploids from anther culture has been reported for only four cultivars, produced and cultivated in Europe (Niemirowicz-Szczytt \& Zakrzewska 1981; Niemirowicz-Szczytt et a/. 1983). Haploid plants have also been produced by crossing F. x ananassa with Potentilla species where the Potenti/la chromosomes have been eliminated after hybridization (Niernirowicz-Szczytt 1987). In one of these studies (Niemirowicz-Szczytt \& Zakrzewska 1981 ), a combination of IAA, 
BA, and 2,4-dichlorophenoxyacetic acid (2,4-D) was favorable to haploid plant regeneration, with an overall haploid regeneration frequency of approximately $2.5 \%$. Unfortunately, use of this combination of growth regulators did not result in the production of either callus or shoots in preliminary experiments in our laboratory using several North American cultivars. This is not surprising, given the very broad genetic base from which modem, North American cultivars have been developed (Sjulin and Dale 1987). Therefore, a series of experiments was designed to investigate the cultural influences on callus and shoot regeneration from anther cultures of several North American cultivars.

Specifically, the objective of the present study was to successfully regenerate shoots and haploid plants from three current, commercial, North American strawberry cultivars in sufficient quantities to be useful in a strawberry breeding program. Further, we wished to examine and quantify the effects of several cultural factors (plant growth regulators, carbohydrates, inorganic basal media, culture medium gelling agent, iron chelate, and light exposure and quality) on shoot regeneration and haploid plant production across all three cultivars examined in order to develop a procedure with the potential to be applicable to a range of North American cultivars. These factors were examined in three separate experiments, for the purpose of manageability, and sequenced in terms of their expeCted influence, from highest to lowest, after an examination of previously published tissue culture media developed for a range of plant genera, including Fragaria.

\section{Materials and Methods}

In all experiments, three cultivars were examined ('Chandler', a California variety, and 'Honeoye' and 'Redchief, two varieties developed for the eastern United States). All treatments utilized $10 \mathrm{ml}$ semisolid medium (see individual experiments) in $15 \times 60 \mathrm{~mm}$ petri plates, 15 anthers $(1 \mathrm{~mm}$ length, uninucleate stage) per plate, and five plates per treatment ( 75 anthers per treatment). Floral buds were surface-sterilized by a $30 \mathrm{sec}$. dip in $70 \%$ ethanol, followed by inunersion in a $5.25 \%$ sodium hypochlorite solution for 20 $\mathrm{min}$. and 3 rinses in sterile, distilled water. Contamination rates were very low $(1-2 \%$, data not shown). All media contained MS vitamins (Murashige \& Skoog 1962) and were prepared to obtain a post-autoclave $\mathrm{pH}$ of5.8 (Owen et aL 1991).

Experiment 1: Two auxins (2 mglliAA or $0.2 \mathrm{mgll}$ NAA), three cytokinins (BA, BPA, or $\mathrm{KIN}$ at $1 \mathrm{mgll})$, and three carbohydrates $(0.1 \mathrm{M}$ sucrose, $0.1 \mathrm{M}$ maltose, or $0.2 \mathrm{M}$ glucose) were examined in corrected MS medium (Owen \& Miller 1992) solidified with $0.6 \%$ Phytagar (Gibco, Grand Island, NY). BPA is structurally similar to BAP, and has recently become commercially available. Glucose was used at $0.2 \mathrm{M}$ to give equivalent moles of available monosaccharide; however, osmotic potentials would be different. A total of 4050 anthers were cultured. Callus formation after 30d dark culture (21-24C) and shoot formation after an additional30d light exposure (16h photoperiod) were recorded.

Experiment 2: Three inorganic medium formulations [MS; Nitsch \& Nitsch 1969 (NN); and $\mathrm{H} 1]$ and two gelling agents $(0.6 \%$ Phytagar or $0.15 \%$ Gelrite (Carolina Biological)] 
were examined in media containing the growth regulators and carbohydrate shown to produce the highest overall shoot regeneration frequencies from experiment 1 (2 mglliAA, 1 mgll BA, and 0.2 M glucose). HI inorganic medium was formulated after a comprehensive examination of basal media reported for successful androgenesis from a broad range of plant species (fable 1 ). Successful anther culture techniques have used a number of different of medium formulations. Thus, $\mathrm{H} 1$ medium was formulated to take into account several of these differences (see discussion). A total of 1350 anthers were cultured. Callus formation after $30 \mathrm{~d}$ dark culture (21-24C) and shoot formation after an additional $30 \mathrm{~d}$ light culture (16h photoperiod) were recorded.

Table 1. Composition of H1 Medium

\begin{tabular}{lrcr}
\hline & M.W. & mg/ & Molarity \\
& 80.05 & 400 & $5 \mathrm{mM}$ \\
$\mathrm{NH}_{4} \mathrm{NO}_{3}$ & 101.10 & 2022 & $20 \mathrm{mM}$ \\
$\mathrm{KNO}_{3}$ & 136.09 & 272 & $2 \mathrm{mM}$ \\
$\mathrm{KH}_{2} \mathrm{PO}_{4}$ & 246.38 & 246 & $1 \mathrm{mM}$ \\
$\mathrm{MgSO}_{4} 7 \mathrm{H}_{2} \mathrm{O}$ & 146.99 & 294 & $2 \mathrm{mM}$ \\
$\mathrm{CaCl}_{2} 2 \mathrm{H}_{2} \mathrm{O}$ & 277.91 & 27.8 & $100 \mu \mathrm{M}$ \\
$\mathrm{FeSO}_{4} 7 \mathrm{H}_{2} \mathrm{O}$ & 372.25 & 37.2 & $100 \mu \mathrm{M}$ \\
$\mathrm{Na}_{2}-\mathrm{EDTA}_{2} \cdot 2 \mathrm{H}_{2} \mathrm{O}$ & 61.84 & 6.2 & $100 \mu \mathrm{M}$ \\
$\mathrm{H}_{3} \mathrm{BO}_{3}$ & 237.85 & 0.024 & $100 \mathrm{nM}$ \\
$\mathrm{CoCl}_{2} 6 \mathrm{H}_{2} \mathrm{O}$ & 249.61 & 0.025 & $100 \mathrm{nM}$ \\
$\mathrm{CuSO}_{4} 5 \mathrm{H}_{2} \mathrm{O}$ & 223.00 & 22.3 & $100 \mu \mathrm{M}$ \\
$\mathrm{MnSO}_{4} 4 \mathrm{H}_{2} \mathrm{O}$ & 241.92 & 0.24 & $1 \mu \mathrm{M}$ \\
$\mathrm{Na}_{2} \mathrm{MOO}_{4} 2 \mathrm{H}_{2} \mathrm{O}$ & 166.02 & 0.17 & $1 \mu \mathrm{M}$ \\
$\mathrm{KI}_{\mathrm{ZnNa}}$ & 471.63 & 9.4 & $20 \mu \mathrm{M}$ \\
$\mathrm{ZnN}_{2}-\mathrm{EDTA}^{4} 4 \mathrm{H}_{2} \mathrm{O}$ & & & \\
\hline
\end{tabular}

Experiment 3: Three light/dark treatments during the initial 30d callus formation period [16h photoperiod white light ( $130 \mu \mathrm{mol} \mathrm{m}-2 \mathrm{sec} 1$ light intensity), $16 \mathrm{~h}$ photoperiod under a yellow \#2208 filter (Almac Plastics, Inc., Akron Ohio )(Stasinopoulos \& Hangarter 1990), or dark culture] and two iron chelates [100 $\mu \mathrm{M}$ Fe-EDT A or Fe-Metalosate (Albion Laboratories, Clearfield Utah)] were examined in the medium shown to produce the highest overall shoot regeneration frequencies across cultivars from experiment 2 (2 mg/I IAA, 1 mg'I BA, 0.2 M glucose, H1 inorganic medium, and $0.15 \%$ Gelrite). A total of 1350 anthers were cultured. Callus formation after $30 \mathrm{~d}$ and shoot formation after an additional $30 \mathrm{~d}$ light exposure ( $16 \mathrm{~h}$ photoperiod) were recorded. Regenerated shoots were rooted in the same medium devoid of growth regulators for 8-12 weeks, transplanted into coarse sand in $10 \mathrm{em}$ pots, and acclimated ex vitro. Chromosome counts from root tips of the 34 plants which were successfully acclimated were made according to Owen \& Miller (1993). 


\section{Results and Discussion}

The best combination of auxin, cytokinin, and carbohydrate for callus formation and shoot production across all three cultivars (53\% and $8 \%$, respectively) was $2 \mathrm{mg} / 1 \mathrm{IAA}$, I $\mathrm{mg} / 1 \mathrm{BA}$, and $0.2 \mathrm{M}$ glucose (Table 2). This combination is very similar to that used previously in strawberry micropropagation media (Boxus 1974 ), and confirms its utility for androgenesis as well as organogenesis. Kinetin was found to be virtually ineffective for stimulating shoot formation at the levels tested in this study. BP A was shown to be only moderately effective. Of the three carbohydrates tested, glucose was moderately effective for callus proliferation ( $46 \%$ ) and superior for shoot regeneration (2.9\%) across the three cultivars and five growth regulators examined. This may be due to the higher osmotic potential of the medium containing $0.2 \mathrm{M}$ glucose than media containing $0.1 \mathrm{M}$ disaccharide. Cultivar differences were observed, particularly for carbohydrate source; however, the combination of glucose/IAA/BA resulted in shoot formation for all three cultivars examined, and thus it was used in the second experiment.

The influence of inorganic basal media and medium gelling agents (experiment 2) on callus formation and shoot regeneration from cultured anthers are listed in Table 3. Across all cultivars and gelling agent treatments, $\mathrm{HI}$ inorganic medium was similar to MS and $\mathrm{NN}$ inorganic medium formulations for callus formation (61\% vs. $59 \%$ and $61 \%$, respectively), but superior for plant regeneration ( $17 \%$ vs. $6 \%$ and $9 \%$, respectively), illustrating that a medium may influence cell division and organ regeneration events differently. Notable differences between HI and either MS or NN include a significant reduction of ammonium nitrate ( $400 \mathrm{mg} / 1 \mathrm{vs} .1650 \mathrm{mg} / 1$ and $720 \mathrm{mg} / 1$, respectively), an increase of potassium phosphate ( $272 \mathrm{mg} / 1 \mathrm{vs.} 170 \mathrm{mg} / 1$ and $68 \mathrm{mg} / 1$, respectively), and an increase of potassium nitrate $(2022 \mathrm{mg} / 1$ vs. $1900 \mathrm{mg} / 1$ and $950 \mathrm{mg} / 1$, respectively). Anthers cultured on either Phytagar or Gelrite regenerated shoots; however, the combination of $\mathrm{HI}$ and Gelrite produced a greater percentage of shoots across all three cultivars (19\%) than HI and Phytagar ( 15\% ). Therefore, HI basal medium and Gelrite were used in the third experiment.

Iron in plant tissue culture media has been shown to catalyze the photo-oxidation ofEDTA to formaldehyde and is involved in light-induced IAA degradation (Hangarter \& Stasinopoulos 1991). These types of photochemical changes in culture media can be prevented with a yellow long-pass filter (Stasinopoulos \& Hangarter 1990). In the present study, we examined the influence of light and iron chelating agent on shoot regeneration frequencies, since the regeneration medium contained IAA. The combination of iron chelating agent and light/dark treatment (experiment 3) produced interesting results (Table 4). In this experiment, callus formation and shoot regeneration were reduced when anther cultures containing Fe-EDTA were exposed to yellow light during the first 30d and shoot regeneration was virtually eliminated when the cultures were exposed to white light. These results show that light is inhibitory to plant regeneration from strawberry anther cultures, presumably by some mechanism other than via EDT Amediated IAA degradation. 

Table 2. Influence of cultivar, carbohydrate source, and auxin/cytokinin treatment on anther culture response ( $\mathrm{n}=75$ for each treatment). All media contained MS
inorganics and vitamins and were solidified with $0.6 \%$ Phytagar.

\begin{tabular}{|c|c|c|c|c|c|c|c|c|}
\hline \multirow{2}{*}{$\begin{array}{l}\text { Treatment } \\
\text { Sucrose }\end{array}$} & \multirow{2}{*}{\multicolumn{2}{|c|}{$\begin{array}{l}\frac{\text { Chandler }}{\% \text { forming \% forming }} \\
\text { callus shoots }\end{array}$}} & \multicolumn{2}{|c|}{$\begin{array}{l}\frac{\text { Honeoye }}{\% \text { forming \% forming }} \\
\text { callus shoots }\end{array}$} & \multirow{2}{*}{\multicolumn{2}{|c|}{$\begin{array}{l}\frac{\text { Redchief }}{\% \text { forming \% forming }} \\
\text { callus }\end{array}$}} & \multirow{2}{*}{\multicolumn{2}{|c|}{$\begin{array}{l}\frac{\text { average }}{\% \text { forming \% forming }} \\
\text { callus shoots }\end{array}$}} \\
\hline & & & & & & & & \\
\hline $\mathrm{IAA}+\mathrm{BA}$ & $65 a^{*}$ & $19 \mathrm{a}$ & $49 \mathrm{abc}$ & $9 \mathrm{a}$ & $57 a b$ & $\mathrm{Ob}$ & $57 a b$ & $9 a$ \\
\hline $\mathrm{IAA}+\mathrm{BPA}$ & 45abcd & 4bede & $53 \mathrm{ab}$ & lbc & $56 \mathrm{ab}$ & $4 a b$ & Slabcd & 3abcde \\
\hline $\mathrm{IAA}+\mathrm{KIN}$ & 43abcd & $\mathrm{Oe}$ & 29defg & $0 \mathrm{c}$ & $23 \mathrm{e}$ & $\mathrm{Ob}$ & $32 \mathrm{fgh}$ & of \\
\hline $\mathrm{NAA}+\mathrm{BA}$ & $32 d$ & 3 cde & $31 \mathrm{efg}$ & $0 \mathrm{c}$ & $23 \mathrm{e}$ & $\mathrm{Ob}$ & $29 \mathrm{~h}$ & 1def \\
\hline $\mathrm{NAA}+\mathrm{BPA}$ & $64 a$ & 3 cde & 43abcde & $1 b c$ & 35 cde & $\mathrm{Ob}$ & $47 a b c d$ & 1 def \\
\hline $\mathrm{NAA}+\mathrm{KIN}$ & $35 \mathrm{~cd}$ & 1de & $25 \mathrm{fg}$ & $0 \mathrm{c}$ & $25 \mathrm{e}$ & $\mathrm{Ob}$ & 28gh & Oef \\
\hline \multicolumn{9}{|l|}{ Maltose } \\
\hline $\mathrm{IAA}+\mathrm{BA}$ & $61 \mathrm{ab}$ & $11 \mathrm{ab}$ & 43abcde & $1 \mathrm{bc}$ & 47abcd & $4 a$ & S0abed & Sabc \\
\hline $\mathrm{IAA}+\mathrm{BPA}$ & 49abcd & $8 \mathrm{abcd}$ & 39abcdef & $0 \mathrm{c}$ & $34 \mathrm{bcde}$ & $\mathrm{Ob}$ & 4lcdef & 3 def \\
\hline $\mathrm{IAA}+\mathrm{KIN}$ & $41 \mathrm{bed}$ & $0 \mathrm{e}$ & $25 \mathrm{fg}$ & $0 \mathrm{c}$ & $23 \mathrm{e}$ & $1 \mathrm{ab}$ & 30gh & Oef \\
\hline $\mathrm{NAA}+\mathrm{BA}$ & $63 \mathrm{ab}$ & 8 bcde & 36bcdefg & $0 \mathrm{c}$ & 49abc & $3 a b$ & 49abcd & $4 \mathrm{cdef}$ \\
\hline $\mathrm{NAA}+\mathrm{BPA}$ & $51 \mathrm{abcd}$ & Tbcde & 43abcdef & $0 \mathrm{c}$ & Slabc & $5 a$ & 48abcd & 4bcde \\
\hline $\mathrm{NAA}+\mathrm{KIN}$ & 49abcd & $0 \mathrm{e}$ & $29 \mathrm{efg}$ & $0 \mathrm{c}$ & $51 a b c$ & $\mathrm{Ob}$ & 43bcdef & of \\
\hline \multicolumn{9}{|l|}{ Glucose } \\
\hline $\mathrm{IAA}+\mathrm{BA}$ & $53 \mathrm{abc}$ & $12 \mathrm{abc}$ & $57 a$ & $9 \mathrm{ab}$ & $49 \mathrm{abc}$ & $3 \mathrm{ab}$ & $53 \mathrm{abc}$ & $8 \mathrm{ab}$ \\
\hline $\mathrm{IAA}+\mathrm{BPA}$ & 48abcd & Sabcde & 31cdefg & $3 \mathrm{bc}$ & $53 \mathrm{abc}$ & $4 a b$ & 44abcde & $4 a b c d$ \\
\hline $\mathrm{IAA}+\mathrm{KIN}$ & $63 a$ & Oe & 35 bcdefg & $0 \mathrm{c}$ & $24 \mathrm{e}$ & $\mathrm{ob}$ & 4ldefg & of \\
\hline $\mathrm{NAA}+\mathrm{BA}$ & $56 \mathrm{ab}$ & 4bcde & $55 \mathrm{ab}$ & $4 a b c$ & $60 \mathrm{a}$ & $\mathrm{Ob}$ & $57 \mathrm{a}$ & 3 bcdef \\
\hline $\mathrm{NAA}+\mathrm{BPA}$ & 49abcd & 1 de & 48abed & $3 \mathrm{bc}$ & $51 a b c$ & $4 a b$ & 49abcd & 3 def \\
\hline $\mathrm{NAA}+\mathrm{KIN}$ & $53 a b c$ & $\mathrm{Oe}$ & $23 \mathrm{~g}$ & $0 c$ & $29 \mathrm{de}$ & $\mathrm{Ob}$ & 35 efgh & of \\
\hline
\end{tabular}

* Values within columns followed by different letters are significantly different $(\mathrm{P}=0.05)$.

Table 3. Influence of cultivar, culture medium gelling agent, and basal medium on anther culture response ( $\mathrm{n}=75$ for each treatment). All media contained $\mathrm{MS}$ vitamins, $2 \mathrm{mg} / 1 \mathrm{IAA}, 1 \mathrm{mg} / \mathrm{BA}$, and $0.2 \mathrm{M}$ glucose.

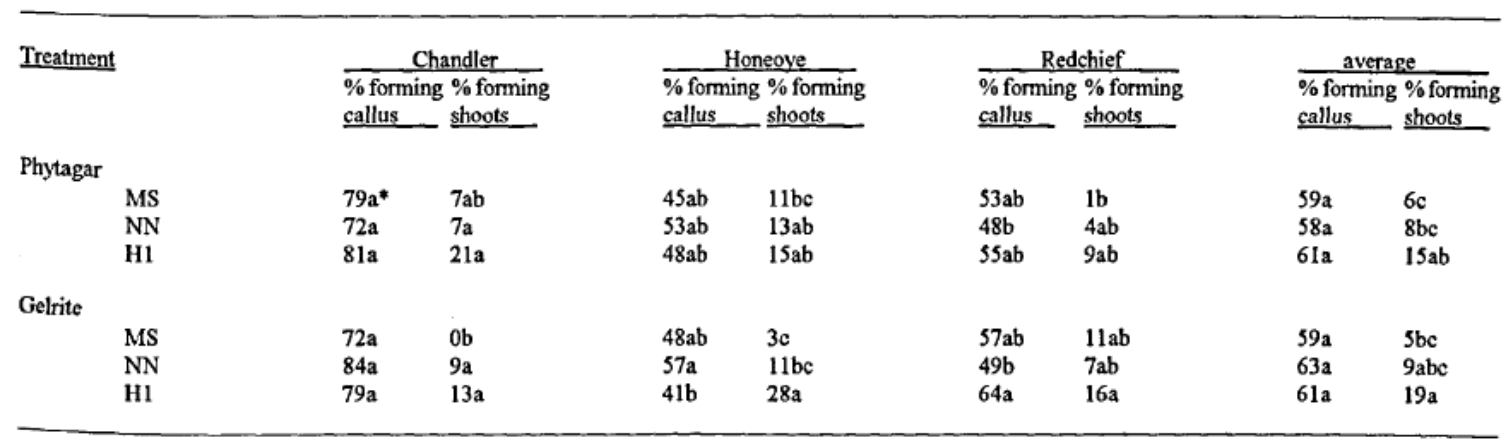

- Values within colums followed by different letters are significantly different $(\mathrm{P}=0.05)$.

Table 4. Influence of cultivar, iron chelating agent, and light/dark treatment on anther culture response ( $\mathrm{n}=75$ for each treatment). All media contained $\mathrm{H} 1$ basal medium, MS vitamins, $2 \mathrm{mg} / \mathrm{IAA}, 1 \mathrm{mg} / \mathrm{BA}, 0.2 \mathrm{M}$ glucose, and $0.15 \%$ Gelrite.

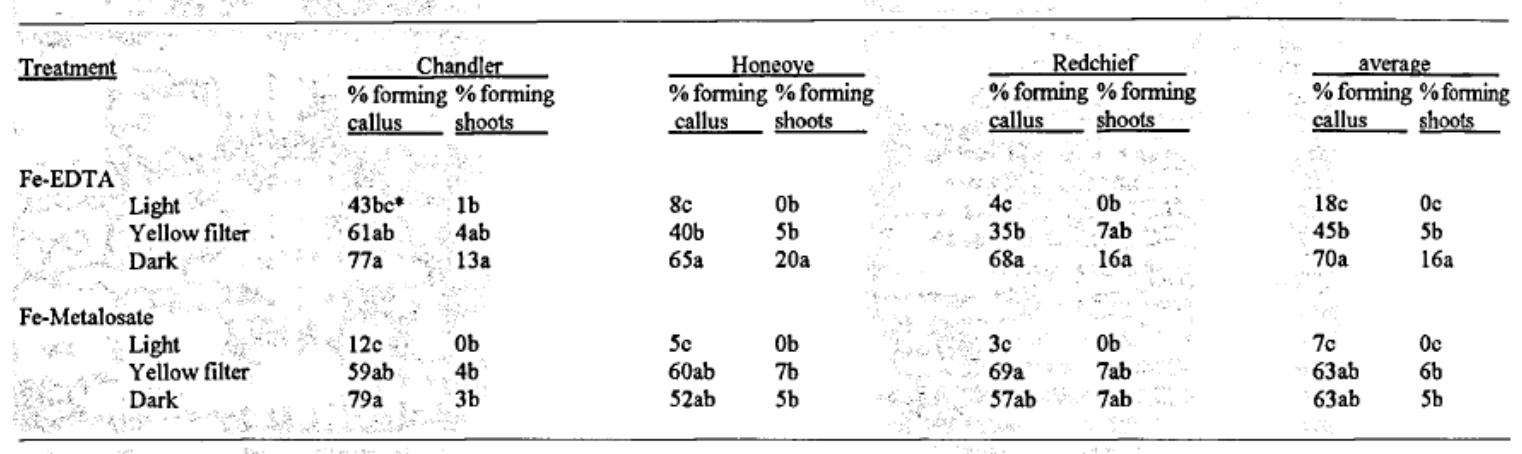

- Values within columns followed by different letters are significantly different $(\mathrm{P}=0.05)$. 
Anthers cultufed on a mediwn containing Iron Metalosate (an amino acid chelate formulation developed for field application). behaved similarly to anthers cultured on a medium containing Fe-EDTA for both callus formation and shoot regeneration when cultures were exposed to white or yellow light, but produced fewer shoots than anthers cultured on a medium containing Fe-EDTA when cultures were incubated in darkness for the initial30d. Additionally, anthers cultured on a medium containing Iron Metalosate and incubated in darkness showed a plant regeneration frequency similar to anthers incubated under yellow light. These results demonstrate that Fe-Metalosate is less effective for shoot regeneration than Fe-EDTA at equal concentrations when cultures are incubated in darkness, but unlike Fe-EDTA it is not inhibitory iil the presence of yellow light. Additional experiments would be needed to determine if other concentrations of FeMetalosate would be effective in increasing plant regeneration frequencies to equal or surpass the frequencies observed with Fe-EDTA for cultures incubated in darkness.

Table 5. Chromosome counts of regenerated plants

\begin{tabular}{lllllll}
\hline $\begin{array}{l}\text { Genotype } \\
\text { designation }\end{array}$ & Mean & SD & & \multicolumn{3}{l}{$\begin{array}{l}\text { Genotype } \\
\text { designation }\end{array}$} \\
C3 & 53.4 & 3.2 & & \\
C4 & 49.2 & 7.5 & C24 & 52.0 & 7.7 \\
C5* & 28.4 & 2.4 & C25 & 32.6 & 3.3 \\
C6 & 52.8 & 2.4 & C26 & 27.4 & 2.1 \\
C7* & 27.2 & 1.9 & C27 & 50.8 & 6.4 \\
C8 & 55.6 & 1.0 & H2* & 28.0 & 2.6 \\
C9 & 55.2 & 1.2 & H9* & 26.0 & 0.9 \\
C10 & 53.6 & 3.4 & H10 & 55.2 & 2.5 \\
C11* & 28.4 & 2.1 & H13 & 52.6 & 3.4 \\
C13 & 55.8 & 2.6 & H14 & 54.4 & 1.5 \\
C14* & 27.2 & 1.5 & H15* & 28.0 & 1.4 \\
C15 & 55.6 & 2.4 & H16 & 53.8 & 2.2 \\
C16 & 54.8 & 2.5 & R3 & 52.6 & 3.9 \\
C18 & 54.8 & 1.9 & R4* & 29.0 & 1.7 \\
C19 & 54.2 & 2.9 & R6 & 50.0 & 2.8 \\
C21 & 54.6 & 3.8 & R9* & 27.4 & 2.0 \\
C23* & 27.8 & 2.5 & R11 & 53.8 & 3.2 \\
& & & R13 & 53.6 & 3.5 \\
\hline
\end{tabular}

\section{$\mathrm{C}=$ Chandler, $\mathrm{H}=$ Honeoye, $\mathrm{R}=$ Redchief, $*=$ haploid range, $\mathrm{n}=10$}

Chromosome counts of regenerated plants are listed in Table 5. Of the 34 plants which survived acclimation to greenhouse conditions, II exhibited chromosome nwnbers within the haploid range $(n=4 x=28)$, giving an overall haploid regeneration frequency of $0.8 \%$ for the fmal experiment. This frequency is lower than the frequency reported by Niemirowicz-Szczytt and Zakrzewska (1981) for European cultivars, but it is within an acceptable range for generating haploids for use in a breeding program. It was not determined whether the 23 plants having chromosome numbers within the diploid range 
were regenerants from somatic cells, or from gametic cells that had doubled during in vitro culture, producing ditetrahaploids. The acclimated plants were grown in a greenhouse and have since flowered and set fruit. Thus, fertility was maintained at the tetrahaploid level, suggesting their potential, after chromosome doubling, for use as homozygous parental material for a traditional plant breeding program. By the anther culture method described in this paper (HI medium, $2 \mathrm{mg} / \mathrm{IIAA}, \mathrm{I} \mathrm{mg} / 1 \mathrm{BA}, 0.2 \mathrm{M}$ glc, $0.15 \%$ Gelrite, $30 \mathrm{~d}$ darkness, 30d light incubation), haploid plants can be produced at frequencies of $0.4-1 \%$ for the three North American cultivars examined. These frequencies are sufficient to allow plant breeders the opportunity to better describe the genetic compliment of desirable cultivars and also use haploid plants in much the same way as inbred lines are used in traditional plant breeding programs. Further studies would be needed to confirm gametic ploidy levels of regenerants (for possible use in interploidy crosses), to determine fertilization mechanisms (male and/or female fertility), and to quantify phenotypic characteristics of the regenerants, including strawberry quality attributes.

Acknowledgements: We thank Joe Scheerens for statistical assistance. This work was supported in part from state and federal funds appropriated to the Ohio Agricultural Research \& Development Center, The Ohio State University, Wooster, OH. Journal manuscript No. 29-95.

\section{References}

Boxus $\mathrm{Ph}$ (1974) The production of strawberry plants by in vitro micropropagation. J. Hort. Sci. 49:20910.

Fowler CW, HG Hughes, J Janick (1971) Callus formation from strawberry anthers. Hort. Res. 11:116-117.

Hangarter RP, TC Stasinopoulos (1991) Repression of plant tissue culture growth by light is caused by photochemical change in the culture medium. Plant Science 79:253257.

Hennerty MJ, AJ Douglas, AJ Sayegh (1987) Studies on androgenesis of the strawberry. Proc. Irish Bot. Mtg., Cork, 25-27 March. p. 76-80.

Laneri U, C Damiano (1981) Strawberry anther culture. Ann. d'Instit. Sperimentale par Ia Frutticoltura 1980, p.43-48.

Murashige T, F Skoog (1962) A revised medium for rapid growth and bioassays with tobacco tissue cultures. Physiol. Plant. 15:473-497.

Niemirowicz-Szczytt K (1987) Strawberry (Fragaria x ananassa Duch.) haploids and their generative progeny. Induction and characteristics. Warsaw Agric. Univ. Press, p.1-64.

Niemirowicz-Szczytt K. Z Zakrzewska (1981)Fragaria x ananassa anthers [sic] cultures. 
Bull. L'Acad. Polonaise Sci. Ser. Sci. Bioi. 28:341-347.

Niemirowicz-Szczytt K. Z Zakrzewska, S Malepszy, B Kubicki (1983) Characteristics of plants obtained from Fragaria $x$ ananassa in anther culture. Acta Hort. 131:231-235.

Nitsch JP, C Nitsch ( 1969) Haploid plants from pollen grains. Science 163:85-87.

Owen HR. AR Miller (1992) An examination and correction of plant tissue culture basal medium formulations. Plant Cell Tiss. Organ Cult. 28:147-150.

Owen HR. AR Miller (1993) A comparison of staining techniques for somatic chromosomes of strawberry. HortScience 28:155-156.

Owen HR, D Wengerd, AR Miller(1991) Culture medium pH is influenced by basal medium, carbohydrate source, gelling agent, activated charcoal, and medium storage method. Plant Cell Reports 10:583-586.

Quarta R, D Nati, FM Paoloni (1991) Strawberry anther culture. Acta Hort. 300:335-339.

Rosati P, M Devreux, U Laneri (1975) Anther culture of strawberry. HortScience 10:119120.

Sayegh AJ, MJ Hennerty (1989) Androgenesis and embryo rescue for strawberry haploid production. Acta Hort. 265: 129-13 5.

Sjulin TM, A Dale (1987) Genetic diversity of North American strawberry cultivars. J. Amer. Soc. Hort. Sci. 112:375-385.

Stasinopoulos TC, RP Hangarter (1990) Preventing photochemistry in culture media by long-pass light filters alters growth of cultured tissues. Plant Physiol. 93:1365-1369.

Svensson M, LB Johansson (1994) Anther culture of Fragaria x ananassa: Environmental factors and medium components affecting microspore divisions and callus production. J. Hort. Sci. 69:417-426. 